n

(1)

(1)

는

$\boldsymbol{\sigma}$

$\cup$

$\subset$

0

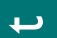

$\varepsilon$

bo

\title{
Interview with Dr. Angela McDonald: Manager at McKinsey \& Company
}

\author{
By Pedrum Mohammadi-Shemirani
}

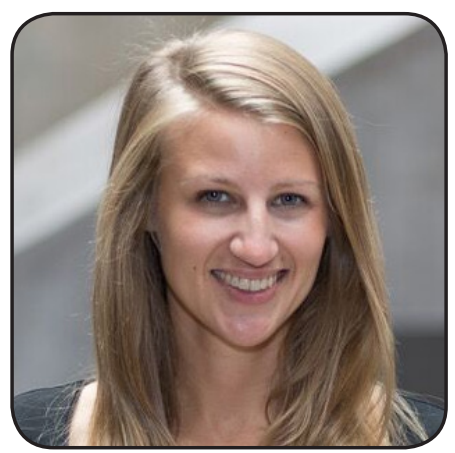

Dr. Angela McDonald is an engagement manager at McKinsey \& Company, a global management consulting firm, where she specializes in the pharmaceutical, medical device, and biotechnology sectors. She completed her PhD in Biomedical Engineering at the University of Toronto in the Institute of Biomaterials and Biomedical Engineering. Her thesis was related to regenerative medicine, and trying to understand gene regulatory networks that drive cell fate in different stem cell populations.

Using a team approach, McKinsey specializes in helping clients solve complex problems and capture opportunities. As an engagement manager, Dr. McDonald primarily manages and coordinates the on-the-ground team, which typically consists of 2-5 consultants. She ensures everyone has the resources needed to complete their tasks and integrates each individual workstream into cohesive recommended actions for the client. She also meets with senior leadership and partners at the firm who guide the team's problem-solving approach. In addition, Dr. McDonald manages the relationship with the client, being the primary point-of-contact for the sponsor from the client's organization.

\section{How did your graduate education prepare you for your career?}

I think it helped two-fold. The first aspect was the problem-solving skills you develop in graduate school. You learn to be very analytical but pragmatic in your problem-solving during a $\mathrm{PhD}$, which is something I use every day here. The teams are often multi-disciplinary with people from all types of backgrounds, and the PhD training really helps give me a solid analytical base.

The second aspect comes from the fact that I work in the same area as my PhD, so l'm able to apply my background knowledge. As a result, I'm able to have thoughtful conversations with the scientists and R\&D departments about the work they are doing and understand it at a deeper level, or participate in work related to a medical device or therapeutic molecules technical properties and feasibility. There are many PhDs who work in areas unrelated to their thesis though, so while they might not use their content knowledge they will still use their analytical skills.

\section{What is your average day/week like? Can you describe a current project you are working on?}

I'll paint the average week. All of my work is done in the US or Europe. Not everyone at McKinsey travels each week but my Monday mornings begin at the airport, where I'm catching my flight to wherever I'm working for that week, usually in Texas, Boston, New York, or Paris. During this time, I'm usually calling my team members in different time zones, and getting everything organized for the week.

From Monday to Thursday, we are with the client. I might be having meetings with them, problem-solving sessions with the team and our partners, sorting out logistics, and providing support for my team. The days on-site will end around 7PM, at which point we will eat dinner together and I will do a few more hours of work in the evening.

On Thursday, I fly back to Toronto. My Fridays are spent at the Toronto office catching up with people here, and on calls with my team and different clients.

Even though I'm not in academia anymore, I still like to be close to science. One of the coolest projects I did was for a client in Europe. They have an innovative medical device that could potentially be used for a bunch of applications, but the client wasn't sure what the best route was. I spoke with lots of different surgeons to understand the problem areas in their procedures, and if there was any room for this device to reduce complications. In the end, we came up with 10 potential applications based on doctors' unmet needs that had reasonable market potential, which we presented to the client. The client went back to the lab to conduct additional 
tests to narrow the list based on the technical feasibility of each application. Now I'm going back to help them think through the development and commercialization model to get their product to the clinic.

\section{What is your favourite and least favourite part about the job?}

My favourite part of the job is all of the learning, which is what I enjoyed about graduate school too. At McKinsey, for 6 weeks I might be working on applications of new polymer technology, then switch to ophthalmology and the major innovations in its therapeutics, followed by vaccines and the technology platforms being used to improve efficacy, or neuroscience and its most promising areas for developing Alzheimer's drugs. You're constantly thinking about new technologies and therapeutic areas, and what markets might look like with these advances.

Everyone definitely works very hard here, but I personally don't dislike that. I would have to say my least favourite part of the job is when I have to wake up at 4:30AM on Monday morning to catch a flight. We don't do that every week, but on some occasions it's necessary.

\section{What is the current demand for MSc or PhD students in your field?}

We hire a lot of advanced professional degrees, which include PhD degree holders. We value the strong analytical skills you develop in these graduate school programs, and we are always looking for smart people who can conceptualize and analyze complex problems.

The traditional track to business consulting is graduating with an undergraduate degree and entering into a business analyst role, or an advanced professional degree into an associate role. MSc students usually come in at the business analyst level, but we hire lots of Master's students as well.

\section{Do you have any advice for current graduate students who would like to envisage a similar career path?}

I'd say to just get out there and talk to people. Start building your network. Talk to people who are working as consultants to really understand what the job is. I know it took me a while to wrap my head around what it means to be a consultant. The interview process is pretty rigorous and it takes effort to prepare for, so you should evaluate whether it's something you want to do. Once you've made your decision, you can put all your effort into the interview. A portion of the interview is a case interview, where you will be presented with a business problem. This might be a foreign concept to students from science backgrounds, so it's helpful to meet people who you can practice with and learn from. McKinsey knows not everyone is familiar with case studies so we have prep materials available (http://www.mckinsey.com/careers/ interviewing) and recruiters are willing to coach candidates as well. 